\title{
Basic Income in Our Time: Improving Political Prospects Through Policy Learning?
}

\author{
JURGEN DE WISPELAERE \\ School of Social Sciences and Humanities, Fl-33014 University of Tampere, Finland \\ email: jurgen.dewispelaere@gmail.com
}

\begin{abstract}
Following the success of a recent Swiss Citizens' Initiative to grant each citizen an unconditional income guarantee and the Finnish Government's plans to conduct the first national pilot project, the idea of a basic income as a citizens' right has gained much prominence in the policy debate. This article reviews a number of policy developments on the ground through the lens of the policy transfer literature. In the absence of a fully developed basic income in place, proponents must rely on partially implemented schemes or proposals that differ in crucial respects from the basic income ideal. This paper outlines three sets of empirical cases and analyses what (if any) lessons we can draw from them regarding the future of basic income schemes.
\end{abstract}

\section{Introduction}

A few years ago Philippe Van Parijs, one of the leading basic income advocates, wrote that 'universal basic income is now far more than just a philosophical pipe dream' (Van Parijs, 2013: 174). The 2013 victory of a Swiss Citizen's Initiative to hold a referendum on the proposal to grant each citizen a $€_{2800}$ monthly unconditional grant initiated a period of exponential interest in the basic income idea across Europe. ${ }^{1}$ In its wake media outlets en masse started airing the basic income idea, while on the ground grassroots movements advocating the proposal mushroomed. In Finland the newly elected centre-right government announced the introduction of a large-scale basic income experiment in its 2015 Government Programme, and has since taken steps towards establishing a research group with the remit to prepare a pilot study to be conducted in $2017 .{ }^{2}$ While much resistance persists among both policy-makers and the general public, quasi-overnight basic income has nevertheless become a credible alternative to orthodox thinking on combating poverty, economic inequality and crisis austerity. These developments suggest a policy window has opened up to push forward the basic income idea in Europe and elsewhere (Kingdon, 1995). However, increased policy attention and political support counts as a valuable resource only to the extent that it can be 
capitalized upon by effective legislation. Facing up to the harsh political realities of welfare reform driven by principles of activation and austerity, how to proceed in moving the basic income proposal further up the policy agenda takes on a certain political urgency.

One avenue is suggested by the policy transfer literature, which holds that policies are frequently adopted through a process of policy transfer from one jurisdiction to another (Hall, 1993; Dolowitz and Marsh, 2000; Marsh and Sharman, 2009; Shipan and Volden, 2012). Policy transfer operates as a tool for prospective policy evaluation (Mossberger and Wolman, 2003) by examining solutions adopted elsewhere for commonly shared problems. Along the way, decision-makers learn valuable lessons about policy design and implementation (Rose, 1991) but also the political effects of adopting a particular programme (Gilardi, 2010). Two leading mechanisms through which such transfer occurs are 'policy learning' and 'policy emulation' (Shipan and Volden, 2008). Policy learning is a slow deliberate process where policy makers carefully examine how a particular policy has performed elsewhere, drawing lessons for instituting a similar scheme in their own jurisdiction. Policy emulation is a more abrupt process where policy makers imitate a scheme pioneered elsewhere, typically for reasons of immediate political gain. Crucially, either scenario requires that a policy akin to basic income is firmly in operation somewhere; and here lies the rub, because the lively discussion in town halls and cyberspace has yet to be reflected in tangible policy outcomes. ${ }^{3}$

If, as an increasing number of scholars hold, policy transfer is a leading mechanism for policy innovation, a pertinent question for basic income advocates becomes where to turn to for policy inspiration. This article reviews three sets of cases that represent a potentially important policy development for the basic income agenda. The first set concerns legislative efforts where basic income policy has moved beyond debate without achieving full implementation. The second set features policies that are considered as important stepping stones for the future institution of a basic income programme. The third set of cases considers two programmes that have been implemented, but where critical design attributes differ in important respects from what most basic income advocates have in mind. While each of these cases falls short of a full extant basic income example, they are selected because they feature prominently in the debate and basic income advocates often refer to them as examples to be emulated in one way or another. The purpose of this article is to examine what (if any) lessons can be drawn from these distinct cases for the prospects of basic income implementation in the short or middle term.

\section{Lost in Legislation?}

This section outlines several cases where basic income has moved along the policy process without resulting in observable policy outcomes. The move from 
grassroots debate to legislative effort is an important achievement but the fact that, in each case, basic income en route became 'lost in legislation' remains critical.

Ireland is often referred to as an example where basic income made considerable headway onto the policy agenda (Healy and Reynolds, 2000). In 2002, following the Partnership 2000 Working Group on Basic Income, the government commissioned and published a Green Paper, which concluded that a tax-integrated basic income would not only be affordable but have important distributive effects (Healy and Reynolds, 2012). However, the Green Paper (and basic income) was mostly ignored in subsequent policy development. The main role of the Green Paper seems to have been to act as a foil for subsequent analysts to challenge its economic sustainability, and it is no surprise that the mainstream parties afterwards gave basic income a wide berth. Even the Irish Greens, one of the few political parties that adopted basic income in its election platform, never acted on its commitment when it (briefly) became a government coalition partner in 2007. This last observation illustrates the political difficulties basic income faces even when advocates are in a position to influence the legislative agenda (De Wispelaere, 2015).

A similar fate seems to have befallen legislative efforts in the US. After a marked interest in guaranteed income in the 1960 s and early 1970s, policy attention seems to have shifted decidedly towards support of the working poor through the Earned Income Tax Credit (EITC) in combination with residual programmes such as Temporary Assistance for Needy Families (TANF) (Steensland, 2006; Caputo, 2012; Widerquist and Sheahen, 2012). A recent attempt to legislate for a basic income guarantee by building on the tax credit mechanism proved ill-fated. In 2006, the Tax Credit for the Rest of Us Act (HR 5257) was introduced in the $109^{\text {th }}$ US Congress by the then congressman Bob Filner (DCA), co-sponsored by Jesse Jackson (D-IL). The Act proposed 'to transform the standard deduction and personal exemptions into a refundable standard tax credit (STC) of $\$ 2,000$ for each adult and $\$ 1000$ for each child' (Widerquist and Sheahen, 2012: 25), which would include the non-working poor. Despite extensive lobbying by the late $\mathrm{Al}$ Sheanen (one of the originators of the proposed legislation), the Act failed to gather legislative momentum and is currently stuck in the House Ways and Means Committee. Basic income development in the US has since largely been relegated to grassroots movements.

The previous cases illustrate how basic income makes an entrance onto the policy scene but fails to gain a proper foothold in legislation. However, even when legislation is in place, all is not necessarily well. The most telling example of basic income becoming 'lost in legislation' is Brazil, where in 2004 President Lula da Silva signed the Lei de Renda Básica de Cidadania into law. Widely heralded by basic income advocates as a major victory, Law No. 10.835 has achieved little more than enshrining the basic income 'principle' into Brazilian legislation. Although 
by all accounts a unique political achievement, in practice the Lei is hampered by internal contradictions and provisions accommodating an executive opt-out. One concern is that a law meant to legislate for a universal grant contains a provision that the government implement the law in stages, targeting the poorest (Lavinas, 2012). 'Its format thus combines mutually exclusive requirements, targeting the poorest and aiming for uniformity and universality' (Lavinas, 2012: 30). ${ }^{4}$ This problem is compounded by the absence of a timetable for implementation and the Leis subordination to budgetary and developmental priorities at the sole discretion of the Executive.

During the same period Brazil has devoted all its resources to instituting the Bolsa Família, its flagship conditional and means-tested programme. Although the leading proponent of basic income in Brazil, ex-Senator Eduardo Suplicy, believes this to constitute a step towards instituting a full Citizen's Basic Income, critics insist the Bolsa Familia has usurped the basic income legislation (Lavinas, 2012; LoVuolo, 2012). The recent discovery of 15.1 to 20.5 billion barrels of oil and gas in the pre-salt fields, a petroleum windfall with marked similarities to the case of Alaska (discussed below), generated political debate but failed to kickstart the budgetary process required to implement the basic income as stipulated by Law No. 10.835 (Lavinas, 2012: 42-43). Nearly a decade after legislating for a Citizen's Basic Income, precious little of an unconditional income guarantee is seen on the ground.

\section{Selective Policies as Universal Stepping Stones?}

The cases above may have pushed basic income part-way along the legislative route, but failed to deliver actual policy outcomes. An alternative route is to examine whether selective policies could serve as stepping stones upon which to build a future basic income policy. Jordan (2012) calls this the 'low road' to basic income. In principle many schemes or programmes can facilitate subsequent policy development but, in what follows, I focus on two programmes that have been put forward as genuine stepping stones within the basic income community.

Conditional Cash Transfer (CCT) programmes have become one of the dominant anti-poverty tools in Africa and Latin-America (LoVuolo, 2012). The details vary but the general approach in all cases is to combine short-term poverty alleviation with long-term human capital building (Sandberg, 2015). A typical scenario is for poor households with children to receive a cash grant on condition of school attendance and regular health check-ups for children. Failure to comply with these conditions may result in financial penalties or being removed from the programme. The resulting incentives, proponents argue, ensure not only effective poverty alleviation but also a significant positive impact on health and education, which is a strong factor in reducing poverty in the long run (World Bank, 2009). ${ }^{5}$ 
CCTs play an important role in establishing the superiority of cash transfers, to be used by the recipient without strings attached, over vouchers or food aid in addressing issues of poverty and social inequality (Standing, 2008). CCTs of course remain highly conditional which conflicts with the universal approach taken by basic income advocates. LoVuolo (2012: 7) asks 'whether [CCTs] can then be viewed as a first step toward the application of a [basic income]' or instead 'constitute a deterrent for such a proposal?' While some seem optimistic that there is a straightforward road from CCTs to a more universal and inclusive unconditional transfer approach (e.g. Standing, 2008), the case of Brazil seems to indicate the contrary (Lavinas, 2012). Recent development of the Bolsa Família sees it expanded along workfarist lines (Lavinas, 2012: 39-40), making its transformation into a basic income even less likely. While establishing the case for using cash transfers rather than directed aid, CCTs plant firm hurdles in the way of grafting an unconditional basic income approach onto this basis. The resulting path dependence should not be underestimated (Pierson, 1993).

Reviewing a second policy development that has recently been likened to a basic income precursor, Jordan (2012: 1) argues that a first step towards the establishment of a universal basic income lies 'concealed within a load of cuts, conditionality and means-testing' of the Universal Credit. The UK has embarked on a major overhaul of the welfare system to make work pay and reduce administrative waste and fraud by integrating several benefit programmes into a refundable tax credit that applies a single, progressive withdrawal rate to in-work benefits (Brewer et al., 2012: 41). Combined with increasingly stringent work requirements, the Universal Credit is meant to incentivise recipients to work (or work more) by allowing them to retain more of their benefits even when working in so-called mini-jobs (low pay, few hours work). The newly minted programme has proven highly contentious, even before its fraught implementation (and 'amber-red' status) became public knowledge. Estimates suggest work incentives will not be universally positive and, contrary to the proclaimed aims, many workers will face higher marginal deduction rates and still face a serious benefits trap (Brewer et al., 2012). Paired with increased work conditioning for groups currently out of work, claims by the government that the Universal Credit will generally benefit low-income groups seem hard to sustain in light of the focus on cuts as part of the coalition's austerity programme (Dean, 2012).

While he is perfectly aware how far removed Universal Credit is from the basic income ideal, Jordan $(2011,2012)$ insists that tax benefits integration is a precondition for - and thus one big step towards - establishing a basic income. ${ }^{6}$

But whereas New Labour's tax credit scheme emphasised the difference between in-work support and out-of-work benefits, the new proposals aim at simplicity and consistency by integrating benefits into the tax system, and this is the step which opens up the way to gradually de-stigmatizing all state payments, and ultimately removing all the conditions which surround them. (Jordan, 2011: 2-3). 
Others have similarly emphasised tax benefits integration as a necessary condition for basic income to genuinely have a universal scope (LoVuolo, 2012; Healy and Reynolds, 2012).

Granting Jordan and LoVuolo their view that tax benefit integration is a key element for making basic income work, the question still remains whether a highly conditional programme such as the UK Universal Credit should really be regarded as a stepping stone towards basic income. Jordan seems to waver on this point. On the one hand, he observes 'there is a real danger that the Duncan Smith reforms will not be the first step towards a more just and equal order, but the consolidation of a profoundly unequal and exploitative one' (Jordan, 2012: 12). On the other hand, he thinks the imperative of cost-saving will, over time, turn against the labour market activation components, resulting in a more relaxed attitude towards voluntary participation instead of work conscription (Jordan, 2012: 14). Unfortunately, historical evidence and public opinion shows a persistent moral division between the deserving and undeserving poor (van Oorschot, 2000; Taylor-Gooby, 2013), the so-called 'cultural categories of worth' permeating the ideology of the welfare state in Europe and the US (Steensland, 2006). ${ }^{7}$ This gives us little reason to think conditions of need and, especially, willingness-to-work will disappear any time soon merely because they are costly. In the absence of identifiable policy levers that move us towards a genuinely universal scheme, we have little reason to regard tax benefit integration in the UK as anything but a scheme that reinforces the workfare state.

\section{Celebrating Success Stories? Alaska and Iran revisited}

Two programmes that have been implemented in Alaska and Iran constitute the most important reference points for basic income policy transfer. In addition to insights about the political process, in these cases policy-makers can also learn lessons about programme design and implementation. However, I argue below that it is precisely the particular policy attributes of the Alaska and Iran schemes which hamper drawing lessons that are applicable to the basic income proposal.

\section{Alaska's Permanent Fund Dividend}

When basic income advocates talk about existing basic income policies, they principally point to the Alaska Permanent Fund Dividend (PFD), which since 1982 has paid each eligible resident an unconditional annual grant (Widerquist and Howard, 2012a). The Alaska scheme comprises two separate programmes: the Alaska Permanent Fund (APF), a publicly owned investment portfolio funded by 25 per cent of the state's oil revenue, and the Permanent Fund Dividend (PFD) which, in 2014, allocated an annual grant of $\$ 1,884$ to each man, woman, and child who meets the residency requirement. ${ }^{8}$ The PFD has proven to be a 
very successful programme, enjoying tremendous support from citizens across demographic, socio-economic, and political divides, despite recent pressure due to Alaska's budget crisis. As Goldsmith (2005: 558) pointedly relates, in Alaska today it amounts to 'political suicide to suggest any policy change that could possibly have any adverse impact today, or in the future, on the size of the PFD.'

Is the Alaska model a good example of a basic income scheme? While the PFD meets the conditions of universality, individuality and unconditionality (Widerquist and Howard, 2012b), several elements of the Alaska dividend limit its usefulness for the basic income debate writ large. The first is the meagre level of the grant: fluctuating between a low of \$628 (in 1984) and a high of $\$ 2533$ (in 2000) (Goldsmith, 2012 [all figures in 2010 dollars]), the level of the dividend is substantially smaller than what basic income advocates - even those advocating a modest partial basic income - have in mind. ${ }^{9}$ My concern here is not just with the low level of the grant but with the amount fluctuating significantly from one year to the next, which is highly problematic for any policy that has anti-poverty or equality-promoting ambitions (Zelleke, 2012). This raises questions about generalising insights from the Alaska dividend to the expected individual-level or aggregate effects of introducing a basic income.

A different concern arises from the particular funding source of the Alaska dividend and its associated politics. Resource dividends is one model that can be used to finance and justify an unconditional basic income, but it has very peculiar features that may poorly apply to models rooted in raising income or consumption taxes, or reducing other social programmes to secure its funding. Many commentators insist resource dividends are windfall gains that appear to create little opposition as they do not rely on appropriation or disentitlement. 'No one has reason to feel burdened by its creation and continued existence. The yearly dividends are financed by the returns on state-owned investments. They don't cut into anyone's perceived ownership' (Widerquist and Howard, 2012b: 226). But, if this is true, one cannot help but wonder why the Alaska scheme is the only one of over 50 Sovereign Wealth Funds that pays out individual dividends (Cummine, 2012)? One answer to this puzzle may be that 'the case for a resourcefunded basic income policy may not be compelling prior to its enactment', even if it becomes 'very popular very quickly once instituted' (Bryan and Castillo, 2012: 74). The politics of resource dividend predistribution is distinct from the traditional politics of redistribution (Korpi and Palme, 1998; Taylor-Gooby, 2013).

But herein precisely lies another problem, for a basic income grounded in a resource dividend scheme may fail to be properly accountable, and even become regressive. On accountability, Bryan and Castillo (2012: 77) argue that, since governments don't have to obtain their revenue directly from the electorate, they will perceive opportunity costs of expenditures less clearly and this in turn implies less accountability. The absence of income taxation - the feature that 
makes resource dividends politically palatable - implies that resource-taxed basic income schemes have, at best, a modest impact on inequality reduction but are more likely to have 'an overall regressive effect on income distribution' (Zelleke, 2012: 151). At the very least, this urges caution when relying on the Alaska model as a template for introducing basic income elsewhere.

\section{Iran's Basic Income out of Price Subsidies}

In recent years a second scheme has inspired basic income advocates as a model of how to institute a basic income. Both its location - Iran - and the pathway by which it came about are slightly vexing. Like the Alaska scheme, the Iranian model is based on oil resources. However, in this case, the funding does not come from a sovereign wealth fund, but instead from reforming the price subsidies on consumption. Iran, a major oil producer and exporter, for many years used the proceeds to implicitly subsidise the domestic consumption of private individuals and enterprises by keeping oil prices at one of the lowest levels in the region. ${ }^{10}$ This extraordinary situation is untenable in the long run and, in a move towards rationalisation, in December 2010 Iran initiated the first stage of a five-year reform programme (Tabatabai, 2011, 2012a, 2012b).

The reform programme removes implicit subsidies, which amounts to a manifold price increase, in combination with the provision of a monthly cash transfer of $\mathrm{Rl} 455,000$ (roughly \$45) per resident Iranian. The explicit aim of the transfer is to compensate private individuals, business (e.g. to stimulate use of energy-efficient production technology) and even the government for the cost of rapid price increases on oil and fuel products. ${ }^{11}$ Any effects on poverty or economic inequality are surplus to the goal of effectively rationalising oil consumption without causing a massive uproar or widespread economic devastation.

Cash transfers are universally and uniformly paid independent of means or work tests, albeit to household heads - thus conforming to a de facto basic income (Tabatabai, 2011). The Iranian government initially wanted to restrict the transfer to the 70 per cent of the population with incomes lower than the national average. However, it ran into many practical problems trying to identify the relevant beneficiaries and, in the end, pragmatically decided to drop any restrictions. Tabatabai (2012b) writes ' $\mathrm{r}$ ] ather than alienating a part of the population, the government eventually decided to abandon the exercise and declared everyone eligible for transfers, at least initially. The universal basic income was thus born as a means of ensuring wider public support for the price reform.' While government appealed to the better-off to voluntarily withdraw from the scheme, immediately following implementation 'the number of participants rose from 60 million to 72.5 million, or from 80 per cent of the population to 96 per cent' (Tabatabai, 2012b: 22). The near-universality of the basic income grant in Iran emerged quasi-spontaneously, rather than by design. 
There are several intriguing features to the Iranian model. First and foremost, there is a marked similarity with the Alaska dividend in that the main concern was resource management rather than providing a guaranteed income floor to resident Iranians out of concerns with poverty or inequality. Tabatabai (2012b: 24) explains: 'the birth of a de facto basic income owes much to the fact that cash transfers are universally seen as compensation for the loss of subsidies, not as a right or entitlement without a quid pro quo. That is how the hurdle of reciprocity was overcome.' In Iran, even more so than in Alaska, basic income emerges as a byproduct of economic policy. In both cases, the boost in income security was a fortunate side-effect (Elster, 1983).

The question remains whether the model is easy to export elsewhere. In Iran, several factors combine to explain the fortuitous emergence of basic income: a pre-existing (implicit) price subsidy on a widely consumed good, at a level that is so high it is both distortionary - which gives government strong incentives for reform - and able to fund a basic income (through its price differential after reform). The closest alternative for countries where such clear-cut price subsidies are not present would be a basic income funded through a consumption or a green tax, which embodies a distinctive type of politics by departing from the focus on compensating-for-loss that defines the Iranian experience. The Iran case constitutes a clear example of the politics of blame-avoidance (Weaver, 1986; Hood, 2002).

Moreover, even in Iran, it is an open question whether the current cash transfer system will remain in place once the five-year reform period is completed. Government may decide to keep the cash transfer nominally in place but at a deflated real value, thus eroding the income guarantee component of this basic income (De Wispelaere and Morales, 2015). ${ }^{12}$ The immediate challenge, however, appears to be the intense financial pressure on the system: in part because of miscalculating the expected revenue and in part because of increased demand after eligibility criteria were relaxed; 80 per cent of the revenue from higher fuel prices goes towards funding private household transfers (instead of the originally budgeted 50 per cent). With the budget fixed by law, the future stability of the programme requires a significant adjustment by either reducing the transfer amount for all or else giving up on the principle of near-universality and reintroducing the notion of eligibility criteria (Tabatabai, 2012a, 2012b). Neither solution is very appealing from the perspective of a basic income guarantee. ${ }^{13}$

Comparing the Iranian experience of public support with that of Alaska, where the mere implementation of the PFD and the receipt of regular dividends appeared to have built its own constituency (Goldsmith, 2005, 2012; Bryan and Castillo, 2012; Widerquist and Howard, 2012b), reveals important differences. In Iran, the prospect of subsidy reform caused major anxiety across the population, and the purpose of the cash transfer was precisely to stymy public concern. In part this was successful, as the population by-and-large seems to have accepted the 
reform. Nevertheless, the public response to the scheme is far from universally supportive. Many think compensation is better 'redirected to other priorities, for example, job creation or expansion of public services' (Tabatabai, 2012b: 30). There is certainly no support for universality as such. The results of a recent opinion poll seem to suggest that a majority (62 per cent) doubt the transfer is able to cover the extra expenses due to increased fuel prices for most households. Further, more people rate the likelihood of the cash transfers enduring over time as low or very low compared to those who rate it high or very high ( 42 per cent compared with 36 per cent) (Tabatabai, 2012b: 30 ). Interestingly, whereas in the Alaska case there seems to have emerged a strong political constituency in favour of dividends, in Iran the public support remains comparatively weak.

\section{A Policy Learning Agenda for Basic Income}

Returning to the policy transfer framework, what lessons can we draw from the examples discussed above? Each of the examples discussed above, selected primarily because of how they are perceived within the basic income epistemic community, constitutes a case study in the intricate politics of basic income. Inevitably, case-specific features play an important role when attempting to explain instances of failure to develop into a full-blown basic income policy or even predict the prospects of basic income emerging in the near future. The pertinent question for this article, however, is whether there are common challenges that we can identify in each case, and what (if any) lessons can be drawn about the policy and political effects of introducing a basic income scheme.

One observation is obvious when surveying attempts to move basic income up the political agenda: pushing government to seriously consider legislating and implementation a basic income is proving to be quite a challenge. For this reason, straightforward policy emulation of even the most developed schemes is ill-advised. By contrast, policy learning as a mechanism for policy transfer requires that policy makers carefully examine not only the performance of the policy in situ, but also consider the extent to which the circumstances of the policy context are sufficiently comparable to allow for policy transfer (Rose, 1991; Shipan and Volden, 2008, 2012). In this respect, the cases outlined offer insight about the core features in the policy process to be negotiated, and guidance about strategies to overcome the hurdles en route to policy implementation.

Case studies suggest campaigns to directly push for a basic income guarantee are easily blocked at various points on the long (and winding) road towards legislation. The cases of Ireland and the US demonstrate how important windows of opportunity nevertheless fail to produce basic income legislation, with legislative efforts effectively thwarted. Basic income advocates often point at observable successes, such as the Irish Government producing a Green Paper, in a way that fails to appreciate the many political hurdles that must be scaled 
before basic income becomes policy reality. A critical problem besetting basic income is the misplaced optimism attached to gratuitous support from policy entrepreneurs or political parties, which fails to pay off in terms of resources spent to overcome political obstacles (De Wispelaere, 2015). Equally important is the dearth of systematic comparative research into the conditions under which basic income proposals enter the policy process and what factors hamper its development. ${ }^{14}$ In this regard, a clear view of the totality of the policy process from idea to reality and, in particular, the many institutional veto points that need to be overcome is essential. A political approach that puts all effort and resources into getting basic income onto the first step of the policy ladder, only to have it falling off along the way, seems shortsighted.

The Brazilian experience is even more instructive of the Herculean proportions of the task at hand. Despite having dedicated basic income legislation on the books, the odds of the Lei de Renda Básica de Cidadania ever becoming instituted in a way that remains faithful to its aspirations now seem remote. Lavinas (2012) points out that this is partly due to how the law itself was drafted - small compromises in wording for the sake of getting the legislation approved are now having a disproportionately negative impact - but also because of the broader policy context, notably the existence of the Bolsa Familia as a dominant competitor. The Brazil experience confirms what we know from comparative policy research, namely that the layering of programmes and the internal competition this generates, reduces the stability of a policy (see Schickler, 2001; De Wispelaere and Morales, 2015). Basic income advocates must be mindful that programmes that appear to be serving a similar purpose rapidly end up becoming competitors for scarce organisational and budgetary resources. There is an important political lesson to be learned about compromising legislative efforts in a way that subsequently renders the implementation of a basic income scheme hostage to the whims of political agents with little sympathy for (or interest in) the programme. The larger lesson, shared with the previous cases, is an appreciation of the difficulties of pushing through a basic income without having secured sufficient political support to steer the proposal around the many bottlenecks in the legislative process.

Basic income stepping stones, such as the CCT programmes in place throughout Latin America or (more controversially) the Universal Credit in the UK, may offer a more feasible approach to instituting basic income by explicitly adopting an incremental approach of 'muddling through' (Lindblom, 1959). Its proponents argue that the low road to basic income already puts in place some key conditions - such as the role of cash transfers or the integration of tax and benefits - without which a well-functioning basic income would not be feasible. With these steps already in place, the subsequent rolling out of basic income should prove much easier. Policy incrementalism has much to speak in its favour, but we should not overestimate the advantages of the low road to basic income. The fact 
that some background conditions are required does not mean that having them already in place implies a decisive advantage. If it is relatively easy to institute these conditions at a later stage, the alleged benefits of using cognates as a stepping stone are overplayed. Worse, having these background conditions in place may hamper rather than help the case for basic income if a critical policy attribute that is supposed to put us on the low road to a basic income fails to deliver. ${ }^{15}$ In other words, incrementalism does not tell us much about the sequencing of policy preconditions.

A different problem is that moving from here to there is far from 'automatic': incremental approaches still need to identify the policy levers that would transform the cognate policy into a proper basic income, and a failure to do so constitutes a major impediment. Against a background of welfare policy wedded to the idea of means-testing or work-conditionality, even with cash transfers and tax benefit integration in place, conditional cognate policies may simply have moved onto an entirely different path from that of a universal and unconditional basic income - a path from which it is very difficult to deviate over time (Pierson, 1993). ${ }^{16}$ The main lesson of this set of cases is that, in the absence of clear mechanisms that function as policy or political levers, we ought to be careful about imputing the sequence, direction or speed of dynamic policy diffusion (Shipan and Volden, 2008). The 'low road' to basic income is an important contender for a political strategy that takes into account the difficulties of pushing head-on for a basic income guarantee, but having an alternative road does not guarantee its success.

In the PFD in Alaska and the compensations for oil pricing reform in Iran we seem to find policies that, in all but name, amount to a basic income, and are indeed often put forward as models to be emulated elsewhere. Here too, the picture is not as straightforward as is often painted by its advocates. The main problem is that specific policy attributes are of crucial importance for policy diffusion (Makse and Volden, 2011), and too much differentiation may impede the usefulness of any lessons learned from these examples. There is little dispute that the schemes currently implemented in Alaska and Iran leave something to be desired from the perspective of a full-blown basic income guarantee, whether it be the low level and variation of the grant, payment on a yearly basis rather than monthly, payment through households rather than individuals, or indeed uncertainty of the stability of the programme over time. Addressing these shortcomings within the particular policy context in which these schemes emerged may be problematic, for reasons mentioned (Zelleke, 2012; Tabatabai, 2012a, 2012b).

However, the main limitation of these programmes for policy learning lies elsewhere. Both Alaska and Iran provide us with a (limited) basic income as a byproduct of a process aimed at, respectively, creating a sovereign wealth fund (Alaska) or reforming implicit subsidies on oil (Iran). These schemes may be 
performing admirably given their intended purpose, but this purpose is explicitly not to grant each citizen a basic income guarantee. Differences between the two examples aside, the many different grounds by which we can justify a basic income (Van Parijs, 2004) provide us with a radically different rationale for policy development from the one underlying Alaska or Iran. The absence of a wellformulated independent rationale for a basic income guarantee restricts not only the expansion of the extant programmes in Alaska or Iran but, more importantly, also limits their use as models for introducing a basic income elsewhere. ${ }^{17}$ Again, from a policy learning perspective, both the particular design and the context in which they operate may simply be too far removed from the basic income proposals most advocates want to institute; in such cases, any lessons learned are by necessity limited (Rose, 1991).

I believe the cases discussed offer us a glimpse of an important challenge that all share in common. One critical problem besetting each of these cases is that policy entrepreneurs have typically attempted to push for basic income in a policy context without broad political support amongst the general public or crucial stakeholders (Mintrom, 1997). It seems reasonable to assume that sufficient political support at crucial points would not have sidelined the various legislative achievements discussed above. Similarly, the extent to which a low road' strategy succeeds in producing a robust basic income policy will crucially depend on political support to use existing programmes as actual stepping stones rather than policy traps. Finally, in the cases of Alaska and Iran, political entrepreneurship and support played a key role in instituting the respective basic income variants but, even now, the stability of each is under heavy pressure to adapt in ways that basic income advocates oppose. More importantly, in both cases the basic income guarantee component was largely a byproduct of a political process aimed at securing other goals. While even an accidental policy may create the sort of path dependence that secures its stability, engineering political support for a basic income through such a circumstantial route may prove difficult to emulate across jurisdictions. This strongly suggests that, even on the incremental 'low' road to policy implementation, attention needs to be focused on obtaining and maintaining broad support.

\section{Conclusion}

Is basic income a policy whose time has come? The glass-half-full response points at the exponential increase in policy attention as well as a host of examples where basic income seems to have moved beyond activist discussion in town hall (or, more often, the pub) or cyberspace. A cautious glass-half-empty response counters by pointing at the fact that discussion and selective policy initiatives so far have failed to produce anything even remotely approaching the philosopher's pipe dream. Both views need to be complemented by a good dose of political realism (not to be confused with defeatism!), suggesting that the prospects of 
basic income critically depend on how well its advocates manage to negotiate the political pitfalls on the long road from philosophical pipe dream to effective policy.

In this article I examined whether basic income advocates could gain inspiration and insight from several programmes attempted or, in some cases, implemented in the last decade. The underlying assumption is one shared with the policy transfer literature: the optimal strategy for rational policy makers is to examine what happened in other jurisdictions, and explore the desirability and feasibility of undertaking a similar endeavour at home. The particular challenge faced by basic income advocates, however, is precisely the absence of a fully developed scheme in operation. In this situation, basic income advocates might try to learn key lessons from cases that offer at least partial insight in moving basic income up the political agenda: these cases include legislative efforts that were halted midway in the policy process, conditional programmes that could serve as key stepping stones for future basic income enactment, and two basic income variants implemented in Alaska and Iran.

While none of these offers a straightforward route on which to embark ruling out policy emulation - a policy learning perspective nevertheless allows us to draw important lessons from each of these case clusters. It should be noted that the insights arrived at are suggestive at best, as systematic comparative research in the conditions supporting (or indeed hampering) policy progress is lacking. However, this article has identified the absence of broad political (and public) support as a major impediment shared by the cases surveyed, which suggests building up a strong constituency willing and able to support instituting basic income remains a core priority.

\section{Acknowledgements}

This article is based on material originally published in my doctoral dissertation. I am grateful to Jochen Clasen, Heikki Hiilamo, Olli Kangas, Pertti Koistinen, Bettina Leibetseder, Rubén LoVuolo, José Noguera and Johanna Perkkio for discussion and pertinent comments on an earlier draft of this article. The final draft of this article was written while I was a Visiting Research Fellow at the Department of Politics, International Studies and Philosophy at Queens University.

\section{Notes}

1 http://www.reuters.com/article/2013/10/04/us-swiss-pay-idUSBRE9930O620131004.

2 http://www.basicincome.org/news/2015/10/finnish-government-research-team-designpilots/

3 This article does not discuss a number of recent pilot studies of basic income policies in Latin-America, Africa, and most recently in India (e.g., Davala et al, 2014), all of which raise complications when generalizing to the context of a mature welfare state.

4 As Lavinas (2012: 40) explains, the original bill drafted by Senator Suplicy contained no reference to the controversial last sentence in paragraph 2, which details how the 
implementation will proceed in stages 'at the criterion of the Executive Branch, prioritizing the neediest segments of the population.' This is an example of political compromise on relatively minor design elements having a disproportionate negative impact.

5 The effectiveness of CCTs remains disputed, in part because the more stringent schemes may have dire effects on those households found to be non-compliant (Barrientos and DeJong, 2006; Sandberg, 2015). One important study employing a randomized control trial designed to compare the effects of conditional and unconditional cash transfers (UCTs) found that 'CCTs are likely to be more effective in improving outcomes that may be strongly affected by compliance with the conditions, such as test scores. UCTs may be preferred if there are many non-compliers who might experience strong and socially beneficial effects from regular income support. If non-compliers can be thought of as a vulnerable group in a given context, UCTs may deserve careful consideration given the possible trade-offs indicated in this study' (Baird, McIntosh and Ozlek, 2011: 1749).

6 For a recent critical analysis of the difficulties inherent to instituting in-work tax credits in the UK, see Clegg (2015).

7 The analysis here is specific to the UK, which due to strong institutional isomorphism was able to import its workfare model directly from the US with limited influence from the European social model (Daguerre, 2004).

8 http://www.pfd.alaska.gov.

9 These figures correspond to $1.7 \%$ and $6.4 \%$ of per capita personal income (Goldsmith, 2012: 49-50). Karl Widerquist and Michael Howard (2012b) believe this amount is non-trivial for low income families once we take into account the pooling of resources; even if true, this would mean basic income is not indifferent to personal circumstances (here, household composition).

10 'By official estimates, the subsidy bill in recent years has been of the order of $\$ 100-120$ billion annually, of which 70 percent went to only 30 percent of the population, mostly in urban areas' (Tabatabai, 2012b: 20). Thus, in addition to encouraging massive oil consumption the subsidy also disproportionately benefited the urban population at the expense of the rural, worse-off population.

11 The scale of price increases ranges from $75 \%$ to $2,000 \%$, depending on the item (Tabatabai, 2012a: 290).

12 As a result of the economic sanctions against Iran and the resulting inflationary pressures, the real value of the cash transfer is conservatively estimated to have halved since 2010 (Hamid Tabatabai, personal correspondence on 24/05/2013).

13 Other elements of the Iranian case may also limit its suitability as a general basic income model. Cash transfers are paid to household heads because they are presumed to pay the fuel bill, and are thus the ones entitled to the compensation. Furthermore, the same questions about effects on poverty and inequality that concern critics of the Alaska dividend such as Zelleke (2012) appear in the case of the Iranian cash transfer.

14 A full explanatory account of the political prospects of basic income must adopt a systematic comparative politics approach (Obinger et al, 2012). One option would be to consider how different welfare regimes structure the political opportunities for instituting a basic income (Goodin, 2001). I am grateful to a referee of this journal and to Bettina Leibetseder for pressing me on this point.

15 In the UK example, the current difficulties of practically implementing the reform may lead the government to alter its proposed tax benefit integration in a way that would negate its role in a future basic income policy, or even abandon the approach altogether. The difficulties of integrating the council tax into the proposed scheme is often mentioned in this regard (Royston, 2012). 
16 For a recent empirical analysis confirming this point, see Marchal et al (2014).

17 For instance, they would require a very different measure and understanding of what counts as policy success or policy failure (McConnell, 2010).

\section{References}

Barrientos, A. and DeJong, J. (2006), 'Reducing Child Poverty with Cash Transfers: A Sure Thing?', Development Policy Review, 24: 5, 537-52.

Baird, S., McIntosh, C. and Özler, B. (2011), 'Cash or Condition? Evidence from a Cash Transfer Experiment', Quarterly Journal of Economics, 126, 1709-53.

Brewer, M., Browne, J. and Jin, W. (2012), 'Universal Credit: A Preliminary Analysis of Its Impact on Incomes and Work Incentives', Fiscal Studies, 33: 1, 39-71.

Bryan, J.B. and Castillo, S. (2012), 'Politics, Preservation of Natural Resource Wealth, and the Funding of a Basic Income Guarantee', in K. Widerquist and M. Howard (eds.) Alaska's Permanent Fund Dividend: Examining Its Suitability as a Model. New York: Palgrave.

Caputo, R. (2012), 'United States of America: GAI Almost in the 1970s but Downhill Thereafter', in R. Caputo (ed.), Basic Income Guarantee and Politics: International Experiences and Perspectives on the Viability of Income Guarantees, New York: Palgrave.

Clegg, D. (2015), 'The Demise of Tax Credits', The Political Quarterly, 86: 4, 493-499.

Cummine, A. (2012), 'Overcoming Dividend Skepticism: Why the World's Sovereign Wealth Funds are Not Paying Dividends', in K. Widerquist and M. Howard (eds.), Exporting the Alaska Model: Adapting the Permanent Fund Dividend for Reform Around the World, New York: Palgrave.

Daguerre, A. (2004), 'Importing Workfare: Policy Transfer of Social and Labour Market Policies From the USA to Britain Under New Labour', Social Policy \& Administration, 38:1, $41-56$.

Davala, S., Standing, G., Jhabvala, R. and Kapoor, S.M. (2014), Basic Income: A Transformative Policy for India, London: Bloomsbury.

Dean, H. (2012), 'The Ethical Deficit of the United Kingdom's Proposed Universal Credit: Pimping the Precariat?', Political Quarterly, 83:2, 353-59.

De Wispelaere, J. (2015), 'The Struggle for Strategy: On the Politics of the Basic Income Proposal', Politics, FirstView:DOI: 10.1111/1467-9256.12102.

De Wispelaere, J. and Morales, L. (2015), 'The Stability of Basic Income: A Constitutional Solution to a Political Problem?', Journal of Public Policy, FirstView: DOI: 10.1017/So143814X15000264.

Dolowitz, D.P. and Marsh, D. (200o), 'Learning From Abroad: the Role of Policy Transfer in Contemporary Policy-Making', Governance, 13:1, 5-24.

Elster, J. (1983), Sour Grapes: Studies in the Subversion of Rationality, Cambridge: Cambridge University Press.

Gilardi, F. (2010), 'Who Learns from What in Policy Diffusion Processes?', American Journal of Political Science, 54:3, 650-66.

Goldsmith, S. (2005), 'The Alaska Permanent Fund: An Experiment in Wealth Distribution', in G. Standing (ed.), Promoting Income Security as a Right: Europe and North America, London: Anthem.

Goldsmith, S. (2012), 'The Economic and Social Impacts of the Permanent Fund Dividend on Alaska', in K. Widerquist and M. Howard (eds.), Alaska's Permanent Fund Dividend: Examining Its Suitability as a Model, New York: Palgrave.

Goodin, R.E. (2001), 'Work and Welfare: Towards a Post-Productivist Welfare Regime', British Journal of Political Science, 31:1, 13-39.

Hall, P. (1993), 'Policy Paradigms, Social Learning, and the State: The Case of Economic Policymaking in Britain', Comparative Politics, 25:3, 275-96.

Healy, S. and Reynolds, B. (2000), 'From Concept to Green Paper: Putting Basic Income on the Political Agenda in Ireland', in R. van der Veen and L. Groot (eds.), Basic Income on the Agenda: Policy Objectives and Political Chances, Amsterdam: Amsterdam University Press. 
Healy, S. and Reynolds, B. (2012), 'Pathways to a Basic Income in Ireland', in R. Caputo (ed.), Basic Income Guarantee and Politics: International Experiences and Perspectives on the Viability of Income Guarantees, NewYork: Palgrave.

Hood, C. (2002), 'The Risk Game and the Blame Game', Government and Opposition, 37:1, $15-37$.

Jordan, B. (2011), 'The Perils of Basic Income: Ambiguous Opportunities for the Implementation of a Utopian Proposal', Policy and Politics, 39:1, 101-14.

Jordan, B. (2012), 'The Low Road to Basic Income? Tax-Benefit Integration in the UK', Journal of Social Policy, 41:1, 1-17.

Kingdon, J.W. (1995), Agendas, Alternatives, and Public Policies, 2nd ed. New York: HarperCollins.

Korpi, W. and Palme, J. (1998), 'The Paradox of Redistribution and Strategies of Equality: Welfare State Institutions, Inequality, and Poverty in the Western Countries', American Sociological Review, 63:5, 661-87.

Lavinas, L. (2012), 'Brazil: The Lost Road to Citizen's Income', in R. LoVuolo (ed.), Citizen's Income and Welfare Regimes in Latin America: From Cash Transfers to Rights, New York: Palgrave.

Lindblom, C.E. (1959), 'The Science of Muddling Through', Public Administration Review, 19:2, 79-88.

LoVuolo, R. (2012), 'Introduction', in R. LoVuolo (ed.), Citizen's Income and Welfare Regimes in Latin America: From Cash Transfers to Rights, New York: Palgrave.

Makse, T. and Volden, C. (2011), 'The Role of Policy Attributes in the Diffusion of Innovations', Journal of Politics, 73:1, 108-124.

Marchal, S., Marx, I. and Van Mechelen, N. (2014), 'The Great Wake-Up Call? Social Citizenship and Minimum Income Provisions in Europe in Times of Crisis', Journal of Social Policy 43:2, 247-267.

Marsh, D. and Sharman, J.C. (2009), 'Policy Diffusion and Policy Transfer', Policy Studies, 30:3, 269-288.

McConnell, A. (2010), 'Policy Success, Policy Failure and Grey Areas In-Between', Journal of Public Policy, 30:3, 345-62.

Mintrom, M. (1997), 'Policy Entrepreneurs and the Diffusion of Innovation”, American Journal of Political Science, 41(3), 738-770.

Mossberger, K. and Wolman, H. (2003), 'Policy Transfer as a Form of Prospective Policy Evaluation: Challenges and Recommendations', Public Administration Review, 63:4, 42840.

Murray, M.C. and Pateman, C. (eds.) (2012), Basic Income Worldwide: Horizons of Reform, New York: Palgrave.

Obinger, H., Schmitt, C. and Starke, P. (2012), 'Policy Diffusion and Policy Transfer in Comparative Welfare State Research', Social Policy \& Administration, 47:1, 111-129.

Pierson, P. (1993), 'When Effect Becomes Cause: Policy Feedback and Political Change', World Politics, 45:4, 595-628.

Rose, R. (1991), 'What is Lesson-Drawing?', Journal of Public Policy, 11:1, 3-30.

Royston, S. (2012), 'Understanding Universal Credit', Journal of Poverty and Social Justice, 20:1, 69-86.

Sandberg, J. (2015), 'Between Poor Relief and Human Capital Investments - Paradoxes in Hybrid Social Assistance', Social Policy \& Administration, FirstView: doi:10.1111/spol.12111.

Schickler, E. (2001), Disjointed Pluralism: Institutional Innovation and the Development of the US Congress, Princeton NJ: Princeton University Press.

Shipan, C.R. and Volden, C. (2008), 'The Mechanisms of Policy Diffusion', American Journal of Political Science, 52:4, 840-57.

Shipan, C.R. and Volden, C. (2012), 'Policy Diffusion: Seven Lessons for Scholars and Practitioners', Public Administration Review, 72:6, 788-96.

Standing, G. (2008), 'How Cash Transfers Promote the Case for Basic Income', Basic Income Studies, 3:1, 1-30. 
Steensland, B. (2006), 'Cultural Categories and the American Welfare State: The Case of Guaranteed Income Policy', American Journal of Sociology 111:5, 1273-1326.

Tabatabai, H. (2011), 'The Basic Income Road to Reforming Iran's Price Subsidies', Basic Income Studies, 6:1, 1-24.

Tabatabai, H. (2012a), 'Iran: A Bumpy Road Towards Basic Income', in R. Caputo (ed.), Basic Income Guarantee and Politics: International Experiences and Perspectives on the Viability of Income Guarantees, NewYork: Palgrave.

Tabatabai, H. (2012b), 'From Price Subsidies to Basic Income: The Iran Model and Its Lessons', in K. Widerquist and M. Howard (eds.), Exporting the Alaska Model: Adapting the Permanent Fund Dividend for Reform Around the World, New York: Palgrave.

Taylor-Gooby, P. (2013), 'Why Do People Stigmatise the Poor at a Time of Rapidly Increasing Inequality, and What Can Be Done About It?', Political Quarterly, 84:1, 31-41.

van Oorschot, W. (2000), 'Who Should Get What, and Why? On Deservingness Criteria and the Conditionality of Solidarity Among the Public', Policy and Politics, 28:1, 33-48.

Van Parijs, P. (2004), 'Basic Income: A Simple and Powerful Idea for the Twenty-First Century', Politics and Society, 32:1, 7-39.

Van Parijs, P. (2013), 'The Universal Basic Income: Why Utopian Thinking Matters, and How Sociologists Can Contribute to It', Politics and Society, 41:2, 171-82.

Weaver, R.K. (1986), 'The Politics of Blame Avoidance', Journal of Public Policy, 6:3, 371-98.

Widerquist, K. and Howard, M. (eds.) (2012a), Alaska's Permanent Fund Dividend: Examining Its Suitability as a Model, New York: Palgrave.

Widerquist, K. and Howard, M. (2012b), 'Lessons from the Alaska Model', in K. Widerquist and M. Howard (eds.), Alaska's Permanent Fund Dividend: Examining Its Suitability as a Model, New York: Palgrave.

Widerquist, K. and Sheahen, A. (2012), 'The Basic Income Guarantee in the United States: Past Experience, Current Proposals', in M.C. Murray and C. Pateman (eds.), Basic Income Worldwide: Horizons of Reform, New York: Palgrave.

World Bank (2009), 'Conditional Cash Transfers: Reducing Present and Future Poverty', A World Bank Policy Research Report, Washington, DC: World Bank.

Zelleke, A. (2012), 'Basic Income and the Alaska Model: Limits of the Resource Dividend Model for the Implementation of an Unconditional Basic Income', in K. Widerquist and M. Howard (eds.), Alaska's Permanent Fund Dividend: Examining Its Suitability as a Model, New York: Palgrave. 